\title{
ANALISIS DETERMINASI INFLASI DI INDONESIA
}

\author{
Ari Mulianta Ginting \\ Peneliti Ekonomi dan Kebijakan Publik pada Pusat Pengkajian \\ Pengolahan Data dan Informasi, Sekretariat Jendral DPR RI \\ e-Mail: ari.ginting@dpr.go.id
}

\begin{abstract}
Inflation is one of the macroeconomic indicators of concern for the government. The high inflation rate could disrupt the economy. This study tried to analyze the factors that cause inflation in Indonesia. This study used a qualitative and quantitative approach using secondary data period 2004-2014. The results of the qualitative analysis showed that in the period 204-2014 inflation rate in Indonesia was fluctuated While the results of the regression analysis VECM, indicating that the inflation rate in Indonesia is influenced by the variable of exchange rate, money supply and level of consumption. While the GDP variable has a negative influence on inflation. In order to control the inflation rate the government could use macroeconomic variables such as exchange rates, the money supply well. Besides controlling public consumption at a good level and increase the production of goods and services to meet community needs.
\end{abstract}

Keywords: exchange rate, inflation, money supply and consumption

\begin{abstract}
ABSTRAK
Inflasi merupakan salah satu indikator ekonomi makro perhatian bagi pemerintah. Tingkat inflasi yang tinggi dapat mengganggu perekonomian. Penelitian ini mencoba untuk menganalisis faktor-faktor yang menyebabkan inflasi di Indonesia. Penelitian ini menggunakan pendekatan kualitatif dan kuantitatif dengan menggunakan periode data sekunder 2004-2014. Hasil analisis kualitatif menunjukkan bahwa tingkat inflasi periode 204-2014 di Indonesia berfluktuasi. Sementara hasil VECM menunjukkan bahwa tingkat inflasi di Indonesia dipengaruhi oleh variabel nilai tukar, uang beredar dan tingkat konsumsi. Sementara itu variabel GDP memiliki pengaruh negatif pada inflasi. Untuk mengendalikan tingkat inflasi pemerintah dapat menggunakan variabel ekonomi makro seperti nilai tukar, uang memasok baik. Selain mengendalikan konsumsi masyarakat pada tingkat yang baik dan meningkatkan produksi barang dan jasa untuk memenuhi kebutuhan masyarakat.
\end{abstract}

Kata kunci: inflasi, jumlah uang beredar dan konsumsi, kurs.

Inflasi merupakan salah satu indikator penting bagi perekonomian suatu negara. Inflasi memberikan pengaruh yang cukup besar terhadap pencapaian beberapa tujuan kebijakan makroekonomi, seperti pertumbuhan ekonomi, kesempatan kerja, distribusi pendapatan dan keseimbangan neraca pembayaran. Inflasi juga merupakan dilema yang menghantui perekonomian setiap negara. Perkembangannya yang terus meningkat memberikan hambatan pada pertumbuhan ekonomi suatu negara. 
Untuk itu diperlukan suatu upaya dalam rangka menjaga inflasi pada level yang rendah dan stabil. Dengan menjaga stabilitas inflasi, pelaku ekonomi akan merasa nyaman dalam melakukan aktivitas ekonominya, sehingga dapat membawa dampak positif bagi perekonomian. Dengan kata lain stabilitas inflasi merupakan langkah awal bagi pencapaian stabilitas perekonomian nasional.

Pada dasarnya definisi inflasi adalah kenaikan tingkat harga yang terjadi secara terus menerus, mempengaruhi individu, pengusaha,dan pemerintah. Inflasi secara umum dianggap sebagai masalah penting yang harus diselesaikan mengingat dampak bagi perekonomian yang bisa menimbulkan ketidakstabilan, pertumbuhan ekonomi yang lambat dan pengangguran yang meningkat. Inflasi juga merupakan suatu masalah yang selalu dihadapi setiap perekonomian.

Penelitian yang dilakukan oleh Goujon (2006) tentang inflasi di menemukan bahwa harga beras, nilai tukar dan jumlah uang beredar merupakan faktor determinan dalam menentukan level inflasi di suatu negara. Lebih lanjut Nguyen et al. (2012) dengan menggunakan persamaan tunggal menemukan bahwa inflasi di Vietnam ditentukan oleh variabel jumlah uang beredar, harga beras dan harga dari BBM. Baasir (2003) mengatakan bahwa inflasi di Indonesia terjadi karena beragam faktor yang mempengaruhinya dan inflasi di Indonesia bukan hanya fenomena jangka pendek seperti dalam teori kuantitas dan teori inflasi Keynes. Akan tetapi inflasi di Indonesia merupakan fenomena jangka panjang.

Mengingat begitu banyak faktor determinasi inflasi disuatu negara, maka perlu dilakukan suatu identifikasi sumber pemicu inflasi di Indonesia. Sehingga Penelitian ini bertujuan untuk adalah untuk mengetahui perkembangan inflasi di Indonesia dan menganalisis faktor determinasi inflasi di Indonesia. Sehingga berdasarkan kajian ini diharapkan didapatkan suatu masukan bagi stakeholder terkait pengendalian inflasi di Indonesia.

Penelitian ini mencoba menganalisis pola dan arah hubungan kausal antar variabel-variabel eksogen yang mempengaruhi inflasi di Indonesia. Variabel-variabel yang digunakan dalam penelitian ini terdiri dari inflasi, GDP, nilai tukar, jumlah uang beredar dan konsumsi.

Dalam penelitian ini, menggunakan data sekunder time series periode waktu 2004-2014. Dengan variabel jumlah uang beredar menggunakan data jumlah uang beredar dalam arti luas atau M2, nilai tukar adalah nilai tukar rupiah terhadap dollar Amerika Serikat. GDP menggunakan data produk domestik bruto (PDB) harga konstan 2010. Dan konsumsi menggunakan data konsumsi masyarakat yang dicatat oleh Badan Pusat Statistik (BPS).

Analisis data yang digunakan dengan menggunakan metode VECM sebagai alat ekonometrika perhitungannya pengaruh variabel independen terhadap variabel dependen. Dalam penelitian juga digunakan analisis deskriptif yang bertujuan mengambarkan perkembangan inflasi terjadi di Indonesia dalam periode penelitian. Sebelum melakukan estimasi VECM, harus dilakukan beberapa tahapan seperti uji stasioneritas data, dan uji derajat kointegrasi. Setelah dapat diestimasi menggunakan VECM, analisis dapat dilakukan dengan menggunakan IRF dan variance decomposition.

Secara teoritis, varibel inflasi, GDP, Jumlah Uang Beredar, nilai tukardankonsumsi mempunyai hubungan timbal balik langsung ataupun tidak langsung sehingga ketiga variabel tersebut merupakan variabel endogen. Dengan demikian hubungan variabel tersebut dapat dianalisis dengan menggunakan metode VAR. Adapun model yang digunakan dalam menganalisis hubungan kausalitas antara inflasi, GDP, nilai tukar, jumlah uang beredar, dan konsumsi adalah sebagai berikut: 
$X_{1, t}=a_{1,0}+\sum_{i=1}^{k} a_{1, i} X_{1, t-1}+\sum_{i=1}^{k} b_{1, i} X_{2, t-i}+\sum_{i=1}^{k} c_{1, i} X_{3, t-i}+\sum_{i=1}^{k} d_{1, i} X_{4, t-i}+$

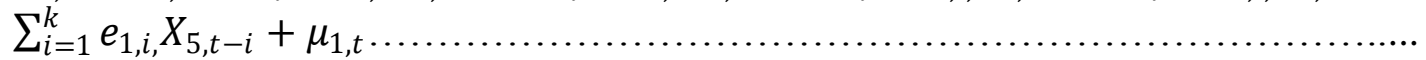

$X_{2, t}=a_{2,0}+\sum_{i=1}^{k} a_{2, i} X_{1, t-1}+\sum_{i=1}^{k} b_{2, i} X_{2, t-i}+\sum_{i=1}^{k} c_{2, i} X_{3, t-i}+\sum_{i=1}^{k} d_{2, i} X_{4, t-i}+$

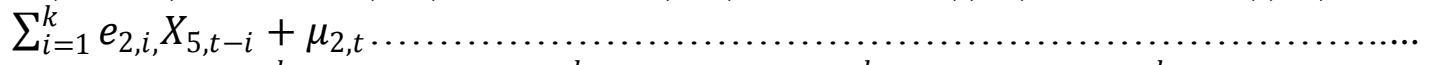

$X_{3, t}=a_{3,0}+\sum_{i=1}^{k} a_{3, i} X_{1, t-1}+\sum_{i=1}^{k} b_{3, i} X_{2, t-i}+\sum_{i=1}^{k} c_{3, i} X_{3, t-i}+\sum_{i=1}^{k} d_{3, i} X_{4, t-i}+$

$\sum_{i=1}^{k} e_{3, i}, X_{5, t-i}+\mu_{3, t}$

$X_{4, t}=a_{4,0}+\sum_{i=1}^{k} a_{4, i} X_{1, t-1}+\sum_{i=1}^{k} b_{4, i} X_{2, t-i}+\sum_{i=1}^{k} c_{4, i} X_{3, t-i}+\sum_{i=1}^{k} d_{4, i} X_{4, t-i}+$

$\sum_{i=1}^{k} e_{4, i}, X_{5, t-i}+\mu_{4, t}$

$X_{5, t}=a_{5,0}+\sum_{i=1}^{k} a_{5, i} X_{1, t-1}+\sum_{i=1}^{k} b_{5, i} X_{2, t-i}+\sum_{i=1}^{k} c_{5, i} X_{3, t-i}+\sum_{i=1}^{k} d_{5, i} X_{4, t-i}+$

$\sum_{i=1}^{k} e_{5, i}, X_{5, t-i}+\mu_{5, t}$

Di mana:

$\mathrm{X}_{1}$ adalah inflasi

$\mathrm{X}_{2}$ adalah GDP.

$\mathrm{X}_{3}$ adalah $\mathrm{M} 2$

$\mathrm{X}_{4}$ adalah nilai tukar

$X_{5}$ adalah konsumsi

$u_{1, t}, u_{2, t}, u_{3, t}, u_{4, t}$ dan $u_{5, t}$, , adalah stochastic error terms.

\section{HASIL DAN PEMBAHASAN}

\section{A. Perkembangan Inflasi di Indonesia}

Inflasi di Indonesia mengalami perkembangan yang naik turun periode tahun 2004-2014 (Lihat Gambar 1). Pada tahun 2004, pada masa pemerintahan Presiden Susilo bambang Yudhoyono relatif berada pada level yang stabil yaitu rata-rata sekitar 6,05\% per tahun. Sedangkan pada tahun berikutnya mengalami peningkatan yang cukup signifikan akibat dampak kebijakan kenaikan harga BBM di Indonesia, sehingga inflasi secara nasional menjadi 10,4\%. Kondisi tersebut terus meningkat hingga akhir tahun 2006. Pada periode tahun 2009-2012, inflasi nasional berada pada level yang rendah dan stabil sekitar 4-5\% per tahun.

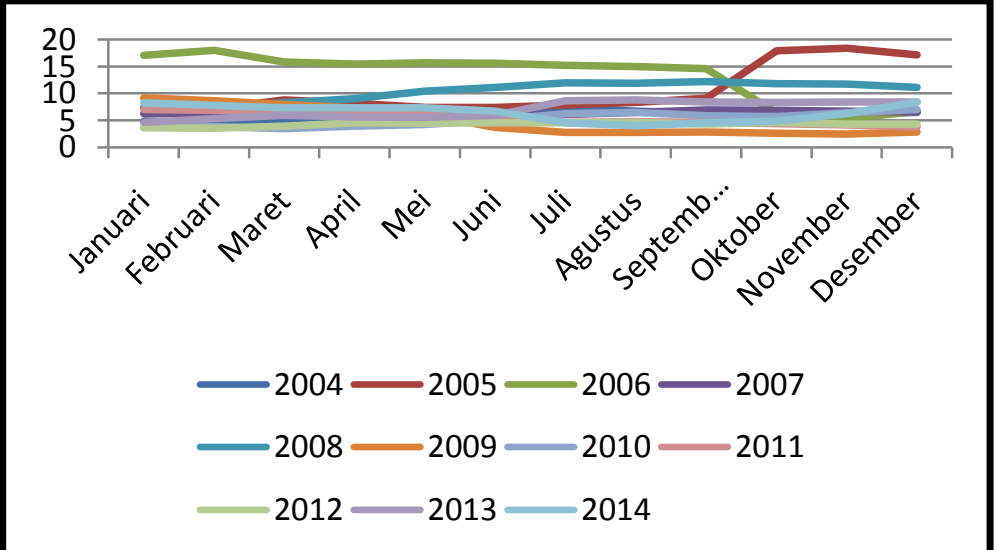

Sumber : BPS (2015).

Gambar 1. Perkembangan inflasi indonesia periode tahun 2004-2014 
Pada tahun 2014, khususnya pada kuartal ke-3 tahun 2014 kembali terjadi tekanan terhadap inflasi. Namun kali ini tekanan inflasi tahun 2014 bersumber dari kelompok administered prices yang meningkat dari tahun 2013. Tingginya tekanan tersebut akibat upaya reformasi subsidi energi yang mencakup liquid petroleum gas (LPG), tarif tenaga listrik (TTL) dan bahan bakar minyak (BBM).

\section{B. Analisis Hasil Estimasi}

1. Hasil Unit Root Test

Hasil uji ADF-test terhadap variabel yang digunakan dalam penelitian ini, seperti terdapat dalam Tabel 1. menunjukkan bahwa seluruh variabel pada tingkat level tidak stasioner. Hall ini dapat dilihat pada nilai test statistic yang secara mutlak memiliki nilai $p$-value atau probabilitas yang lebih besar dibandingkan dengan tingkat signifikansi yang digunakan yaitu $5 \%$. Tetapi setelah dilakukan first difference, seluruh variabel menjadi stasioner dimana nilai test statistic memiliki nilai $p$-value atau probabilitasnya lebih kecil dibandingkan dengan tingkat signifikansi yang digunakan yaitu $5 \%$.

Tabel 1. Hasil Uji Unit Roots dengan ADF-Test

\begin{tabular}{lcccr}
\hline \multicolumn{1}{c}{ Variabel } & ADF-Test & Prob. & ADF-Test & Prob. \\
\hline Inflasi & Level & & \multicolumn{2}{c}{ First Difference } \\
GDP & $-2,448$ & 0,631 & $-6,658$ & 0,0000 \\
Nilai tukar & 1,803 & 0,981 & $-6,767$ & 0,0000 \\
M2 & $-1,868$ & 0,653 & $-5,413$ & 0,0004 \\
Konsumsi & 1,672 & 0,994 & -8.908 & 0,003 \\
Sumber: Hasil & $-0,982$ & 0,935 & $-8,380$ & 0,000 \\
\hline
\end{tabular}

\section{Hasil Uji Kointegrasi}

Berdasarkan hasil unit roots test, seluruh variabel yang digunakan dalam penelitian ini stsioner pada tingkat level. Maka langkah selanjutnya adalah melakukan uji kointegrasi dengan menggunakan Johanesn Cointegration Test. Hasil uji kointegrasi Johansen Cointegration Test dapat dilihat pada Tabel 2.

Tabel 2. Hasil uji Johansen Cointegration Test

\begin{tabular}{lccc}
\hline \multicolumn{1}{c}{ Hipotesis } & Trace Statistic & Critical Value 5\% & Prob. \\
\hline None $^{*}$ & 78,269 & 69,818 & 0,0091 \\
At most 1 & 40,808 & 47,856 & 0,1948 \\
\hline
\end{tabular}

Sumber : Hasil Pengolahan Data (2015).

Tabel 2. memberikan informasi hasil uji Johansen Cointegration Test. Dari hasil tersebut nilai LR Statistik yang terlihat dari trace statistic $(78,269)$ lebih besar dibandingkan dengan nilai critical value $(69,818)$, dimana hipotesis nol adalah tidak ada persamaan kointegrasi $(r=0)$ sedangkan hipotesis alternatif adalah minimal ada satu kointegrasi $(r=1,2, \ldots)$. Sehingga berdasarkan hasil tersebut dapat disimpulkan bahwa minimal ada satu persamaan kointegrasi. Lanjut ke langkah berikutnya, minimal ada satu persamaan kointegrasi, didapatkan hasil bahwa trace statistic adalah sebesar 40,808 lebih kecil dibandingkan dengan critival value sebesar 47,856. Sedangkan hipotesis nol adalah satu persamaan kointegrasi $(r=1)$ sedangkan hipotesis alternatif adalah minimal ada dua 
persamaan kointegrasi $(r=2,3, \ldots)$ sehingga berdasarkan hasil tersebut hipotesis alternatif ditolak. Atau dengan kata lain, hipotesis nol diterima sehingga hanya ada satu persamaan kointegrasi.

\section{Hasil Analisis Model VECM}

Penelitian ini memiliki tujuan mencari hubungan atau pengaruh antar variabel jumlah uang beredar, GDP, nilai tukar, dan konsumsi terhadap tingkat inflasi di Indonesia. Untuk melakukan analisis tersebut maka digunakan model VECM untuk mengetahui hubungan atau pengaruh variabel tersebut. Hasil pengolahan model VECM dapat dilihat pada Tabel 3 berikut.

Tabel 3. Hasil Estimasi VECM

\begin{tabular}{rcccc}
\hline \multicolumn{1}{c}{ Inflasi } & GDP & Nilai Tukar & M2 & Konsumsi \\
\hline Jangka Panjang & \multicolumn{4}{c}{} \\
\hline 1,000 & $-2,081$ & 0,517 & 2,413 & 1,846 \\
& {$[-10,963]$} & {$[2,809]$} & {$[12,827]$} & {$[12,827]$} \\
\hline Jangka Pendek & & & & \\
\hline ECT $=-0.19$ & $-0,469$ & 0,260 & 1,567 & 0,725 \\
{$[-1,906]$} & {$[-1,787]$} & {$[1,822]$} & {$[1,576]$} & {$[1,764]$} \\
\hline
\end{tabular}

[] menunjukkan t-hitung

Sumber : Hasil Pengolahan Data (2015).

Dalam jangka panjang, perubahan pertumbuhan variabel konsumsi, jumlah uang beredar dan nilai tukar memberikan pengaruh yang signifikan dan positif terhadap inflasi di Indonesia. Artinya setiap peningkatan pertumbuhan konsumsi, jumlah beredar dan terjadi depresiasi akan dapat meningkatkan inflasi yang terjadi. Sedangkan perubahan pertumbuhan variabel GDP memberikan pengaruh yang negatif dan signfikan terhadap inflasi di Indonesia. Artinya pertumbuhan output yang diukur dengan pertumbuhan GDP akan dapat menurunkan tingkat inflasi yang terjadi.

Dalam jangka pendek semua memiliki hasil yang sama dengan persamaan jangka panjang. Dimana pertumbuhan variabel nilai tukar, jumlah uang beredar dan konsumsi akan mendorong peningkatan inflasi yang terjadi. Sementara itu pertumbuhan variabel GDP akan justru menurunkan inflasi yang terjadi di Indonesia. Karena salah satu faktor terjadinya inflasi adalah karena demand pull inflation sehingga peningkatna output GDP akan dapat meningkatkan jumlah produksi yang pada akhirya dapat memenuhi kebutuhan barang dan jasa masyarkat.

Hasil penelitian ini sejalan dengan penelitian yang dilakukan oleh Khan et. al. (2007) Laryea dan Sumalia (2001), Abdullah dan khalim (2009), Mosayed dan Mohammad (2009), Khan dan Gill (2010), Abidemi dan Malik (2010), Olatuji,et. al. (2010), Bashir,et. al. (2011) dan Tan (2011). Dari beberapa penelitian sebelumnya juga menemukan hal yang sama yaitu bahwa pertumbuhan nilai tukar, jumlah uang beredar dan konsumsi memiliki pengaruh yang positif terhadap peningkatan inflasi. Sedangkan pertumbuhan output memilik pengaruh yang negatif terhadap peningkatan inflasi.

\section{Impulse Response Function (IRF)}

IRF berfungsi untuk menggambarkan shock variabel satu terhadap variabel lainnya pada rentang periode waktu tertentu. Sehingga dapat dilihat lamanya waktu yang dibutuhkan variabel dependen dalam merespon shock variabel independennya. IRF dalam penelitian ini digunakan untuk menunjukkan respon inflasi terhadap shock determinannnya. Hasil IRF ditunjukkan pada Gambar 2. 


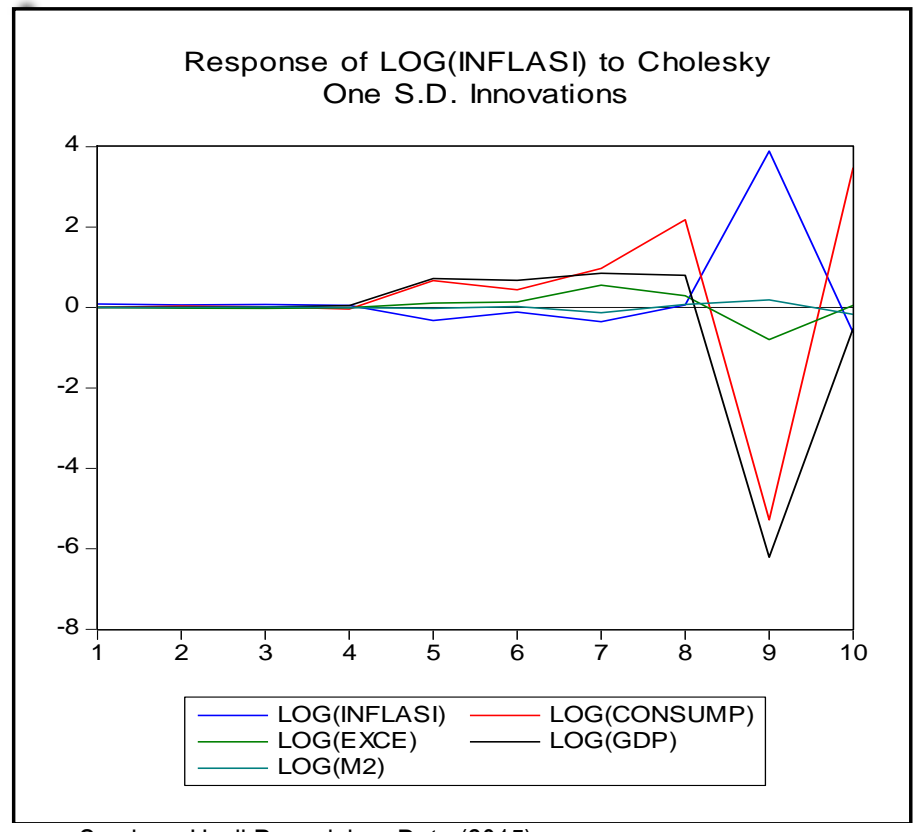

Sumber : Hasil Pengolahan Data (2015).

Gambar 2. Impuls response function variabel inflasi

Gambar 2 menunjukkan respon inflasi terhadap shock variabel nilai tukar. Inflasi merespon shock tersebut dengan tren positif mulai periode ke-4 hingga periode ke-8. Kemudian respon inflasi terhadap shock variabel jumlah uang beredar memberikan tren yang positif mulai periode ke-4 hingga periode ke-8, kemudian respon tersebut memberikan tren yang negatif dan kemudian naik kembali menjadi positif.

Sedangkan untuk respon inflasi terhadap shock variabel konsumsi terlihat respon yang memiliki tren yang positif sampai dengan periode 8 . Respon inflasi terhadap shock dari GDP terlihat tren yang negatif mulai periode ke-8 sampai dengan periode ke-10.

\section{Variance Decomposition}

Tabel 4. Hasil Variance Decomposition

\begin{tabular}{ccccccc}
\hline Variance & \multicolumn{6}{l}{ Decomposition of Log (Inflasi): } \\
\cline { 2 - 7 } Periode & S.E & Log(Inflasi) & Log(Konsumsi) & $\log ($ Exce $)$ & Log(GDP) & Log(M2) \\
\hline 1. & 0,087 & 100,00 & 0,00 & 0,00 & 0,00 & 0,00 \\
2. & 0,115 & 88,18 & 9,11 & 1,37 & 0,29 & 0,03 \\
3. & 0,141 & 88,03 & 7,41 & 2,73 & 0,81 & 1,01 \\
4. & 0,161 & 77,39 & 10,92 & 2,13 & 8,75 & 0,78 \\
5. & 1,054 & 11,15 & 40,64 & 1,14 & 47,00 & 0,05 \\
6. & 1,340 & 7,61 & 36,07 & 1,76 & 54,47 & 0,06 \\
7. & 1,977 & 6,65 & 40,57 & 8,67 & 43,65 & 0,45 \\
8. & 3,067 & 2,80 & 67,46 & 4,51 & 24,96 & 0,24 \\
9. & 9,576 & 16,79 & 37,34 & 1,16 & 44,63 & 0,06 \\
10. & 10,222 & 15,11 & 44,34 & 1,02 & 39,43 & 0,08 \\
\hline
\end{tabular}

Sumber : Hasil Pengolahan Data (2015). 
Variance Decomposition bertujuan untuk mengukur besarnya kontribusi atau komposisi pengaruh masing-masing variabel independen terhadap variabel dependennya. Berdasarkan hasil variance decomposition berikut, pembahasannya hanya difokuskan kepada variabel yang mempengaruhi tingkat inflasi di Indonesia. Dan hasil tersebut dapat dilihat pada Tabel 4.

Hasil dekomposisi menunjukkan para periode satu varian inflasi dijelaskan oleh variable sendiri sebesar $100 \%$. Pada periode selanjutnya, yaitu periode ke-2 sampai dengan periode ke-4 menunjukkan bahwa variabel inflasi dijelaskan signifikan oleh variabel konsumsi dan GDP. Pada Periode ke-5 varian inflasi dijelaskan oleh variabel itu sendiri hanya sebesar $11,15 \%$, sedangkan 40,64\% diterangkan oleh variabel konsumsi dan 47\% dijelaskan oleh variabel GDP, 1,14\% diterangkan oleh variabel nilai tukar dan $0,05 \%$ dijelaskan oleh variabel jumlah uang beredar.

\section{PENUTUP}

Dari hasil pengolahan data pada penelitian ini, penulis mendapatkan beberapa kesimpulan yaitu, perkembangan inflasi tahun 2004-2014 mengalami peningkatan khususnya pada periode tahun 2005-2006 sebagai dampak kenaikan BBM. Pada periode 2009-2013 tingkat inflasi Indonesia berada pada level yang relatif stabil dan rendah, namun pada akhir tahun 2014 kembali inflasi di Indonesia mengalami tekanan akibat dampak perubahan kebijakan subsidi BBM.

Berdasarkan hasil analisaVECM didapatkan kesimpulan bahwa variable nilai tukar, jumlah uang beredar dan konsumsi memiliki pengaruh yang positif dan signifikan terhadap inflasi. Sedangkan variabel GDP memiliki pengaruh yang negatif dan signifikan terhadap inflasi. Untuk itu maka pemerintah harus melakukan pengendalian level inflasi di Indonesia dengan cara mengendalikan nilai tukar pada level yang rendah dan stabil serta mengkontrol secara ketat jumlah uang yang beredar. Disamping itu pengendalian konsumsi masyarakat dirasakan perlu untuk mencegah tekanan yang berlebih terhadap inflasi dampak konsumsi masyarakat. Namun yang perlu diperhatikan pemerintah bahwa diperlukan peningkatan produktivitas untuk menghasilkan barang dan jasa untuk memenuhi kebutuhan masyarakat.

\section{REFERENSI}

Abdulah, M \& Kalim, R. (2009). Determinants of food price inflaton in Pakistan. Paper Presented in the Conference of University of Management Siences.

Abidemi, O. I. \& Malik, S. A.A. (2010). Analysis of inflation and its determinant in Nigeria. Pakistan journal of social sciences, vol.7(2), hlm.97-100.

Baasir, F. (2003). Pembangunan dan crisis. Jakarta: Pustaka Sinar Harapan.

Bashir, Furrukh. Shabaz Nawaz. Kalsoom Yasin. Usman Khurheed. Jahanzeb Khan dan Muhammad Junaid Qureshi. (2011). Determinants of inflation in Pakistan: An economic analysis using johansen co-integration approach. Australian journal of business and management reseach, vol 1(5), hlm.71-82.

Goujon M. (2006). Fighting inflation in a dollarized economy: The case of Vietnam. Journal of comparative economics, vol 34, PP.564-581.

Khan, A. A, Bukhari, S.K. H, \& Ahmad, Q.M. (2007). Determinants of recent inflation in Pakistan. MPRA Paper No. 16254, hlm.1-16.

Khan, A. A., \& Gill, A. R. (2010). Determinant of inflation: A case of Pakistan (1970-2007). Journal of economics, no. 1(1), hlm. 45-51.

Laryea, S.A \& Sumaila, U. R. (2001). Determinants of inflation in Tanzania. CMI working paper, no. 12, HIm, 1-17. 
Mosayeb, P., \& Mohammad, R. (2009). Source of inflation in Iran: an application of the real approach. International journal of applied econometrics and quantitative studies, vol 6(1), hlm.61-76.

Nguyen, H.M, Caroli, T., Wilson. J, K. (2012). The determinants of inflation in Vietnam. ASEAN economic bulletin, no. 26(2), PP.1-147.

Olatunji, G. B. Omotesho, O.A.Ayide, O.E., \& Ayido, K. (2010). Determinants of inflation in Nigeria : A co-integration approach. Paper presented at the joint 3 rd african assocition of agricultural economicst.

Tan Meng Khai. (2011). Determinants of inflation in Malaysia 1919-2010. Reseach report in partial fulfillment of the requirements for the degree of master of business adminstraion. USM Malaysia. 